\title{
Effect of Herbal Preparation on Heavy Metal (Cadmium) Induced Antioxidant System in Female Wistar Rats
}

\author{
P. Dailiah Roopha $\cdot$ C. Padmalatha
}

Published online: 17 November 2011

(C) American College of Medical Toxicology 2011

\begin{abstract}
Cadmium is one of the elements found to damage antioxidant systems in mammals. To ameliorate cadmium toxicity and to prevent oxidative stress, natural products may be useful. In Indian ethnobotanical practice, a mixture of 17 herbal products is used to fortify the reproductive system of women after parturition and to reverse ovarian oxidative stress. Oral administration of this extract to rats exposed to cadmium was useful in reversing oxidative stress. Two different doses of cadmium (50 ppm and $200 \mathrm{ppm}$ ) were given to Wistar rats aged 45 and 65 days. An herbal extract derived from 17 plants was administered orally every day at a dose level of $200 \mathrm{mg} / \mathrm{kg}$ of body weight to the rats exposed to cadmium. A battery of enzymes involved in antioxidant activity in the ovary, including superoxide dismutase (SOD), catalase, glutathione peroxidase (GPx) and glutathione-s-transferase (GST) were measured in the control, cadmium-exposed rats without treatment and in the cadmium-exposed rats treated with herbal extract. The reduction in SOD, catalase, GPx and GST activity after cadmium exposure improved significantly in the rats treated with the herbal extract $(p<0.05)$. The decrease of antioxidant enzymes due to cadmium exposure was reversed significantly with herbal extract administration. The synergistic effect of each bioactive compound in different herbal extracts requires further study.
\end{abstract}

Keywords Medicinal plant extract . Cadmium - Superoxide dismutase (SOD) - Catalase (CAT) - Glutathione peroxidase (GPx) · Glutathione-s-transferase (GST) · Ovary

P. Dailiah Roopha $(\varangle) \cdot$ C. Padmalatha

Department of Zoology,

Rani Anna Government College for Women,

Tirunelveli, Tamil Nadu, India

e-mail: dailiah.roopha@gmail.com

P. Dailiah Roopha

Department of Zoology, Sarah Tucker College,

Tirunelveli, Tamil Nadu, India

\section{Introduction}

Cadmium $(\mathrm{Cd})$ is an environmental risk factor with various toxic effects in animals and humans. Cadmium enters the general environment from the natural weathering of materials, forest fires and volcanoes, but much larger amounts are released by human activities [1]. Cadmium chloride used in photography, photocopying, dyeing, calico printing, vacuum tube manufacture pigment production, galvanoplasty, lubricants, ice-nucleation agents and manufacture of special mirrors [2] may easily enter the environment. Long-term ingestion of large amounts of cadmium has been observed in Japan [3]. The exceptionally long half-life of cadmium in the human body, about 30 years [4], emphasizes the need for the effective assessment and treatment of cadmium toxicity. Cadmium is known to affect reproductive organs $[5,6]$. In the blood and tissues, $\mathrm{Cd}$ stimulates the formation of metallothioneins and reactive oxygen species (ROS), thus causing oxidative damage in erythrocytes and in various tissues. This produces a loss of membrane functions [7].

Oxidative stress is a condition associated with an increased rate of cellular damage induced by oxygen and oxygenderived oxidants commonly known as reactive oxygen species [8]. The cellular damage in the gonads may be due to an improper balance between ROS (reactive oxygen species) generation and scavenging activities [9]. The scavenging potential in the gonad is normally maintained by adequate levels of antioxidant superoxide dismutase (SOD), catalase and glutathione [10]. Long-term exposure to $\mathrm{Cd}$ increases lipid peroxidation and causes inhibition of SOD activity, indicating oxidative damage [11]. The increase in lipid peroxidation (LPO) may be attributed to the alteration in the antioxidant defense system. This defense system includes the enzymes SOD, catalase, glutathione peroxidase (GPx), glutathione-s-transferase (GST) as well as glutathione, which normally protect against radical toxicity. 
A number of plant compounds had been reported to exhibit a protective role against ROS and lipid peroxidation $[12,13]$. In southern India, several herbal products had been reported to fortify the reproductive systems of women and to mitigate oxidative stress due to ROS in the gonads after parturition [14]. The herbal products are collected from different parts of the plants, shade dried and finely powdered, mixed well and given to women soon after parturition. This herbal mixture ("Perukala rasayanam") has been a household remedy used by many women.

This study tests the effect of Perukala rasayanam (PR) on the oxidative stress on ovarian tissue in rats that were affected by $\mathrm{Cd}$ toxicity. The influence of the herbal mixture on the oxidative stress in the ovary is studied after suppressing the antioxidant status in the rat with $\mathrm{Cd}$ exposure.

\section{Materials and Methods}

Thiobarbituric acid, dithio-bis-nitrobenzoic acid, sodium azide and bovine serum albumin were purchased from Sigma-Aldrich Co, St. Louis, USA. Sulphuric acid, hydrogen peroxide, chloroform and sodium hydroxide were procured from Qualigens Fine Chemicals, Mumbai, India. Pyrogallol and petroleum ether were purchased from EMerck (India) Limited, Mumbai, India. All other chemicals were purchased from Sisco Research Laboratories Private Limited, Mumbai, India.

For toxicity evaluations, $\mathrm{Cd}$ (in the form of cadmium chloride) was selected. After preliminary toxicity evaluation, two test doses of $50 \mathrm{ppm}$ and $200 \mathrm{ppm}$ were selected. PR plant products were collected from a local Ayurvedic shop. All plant materials were identified by the Department of Botany, Rani Anna Govt. College for Women, Tirunelveli, Tamil Nadu, India. Then, the plant materials were shade dried.

\section{Preparation of Crude Plant Extract}

The preparation of extract was carried out following the procedure of Uboh et al. [15]. The plant materials viz., Zingiber officinale (rhizome), Piper nigrum (fruits), Trachyspermum ammi (seeds), Brassica nigra (seeds), Ferula asafietida (resin from rhizome), Curcuma longa (rhizome), Anethum graveolens (seeds), Hemidesmus indicus (root), Vernomia anthelmintica (seeds), P. longum (fruits and root), Crataeva religiosa (bark), Allium sativa (bulb), Spilanthes calva (flowers), Alphinia calcarata Roscoe (rhizome), Nigella sativa (seeds), Acorus calamus (rhizome) and Trianthema decandra (root) were collected and shade dried. Two hundred grams of the ground powder was soaked in 1.01 of distilled water for $48 \mathrm{~h}$ at room temperature. The mixture was filtered into a 500-ml conical flask with a Whatman filter paper (No. 1). The filtrate was dried at a temperature of $30^{\circ} \mathrm{C}$ for $10 \mathrm{~h}$ to produce a gel-like extract, which weighed $20.5 \mathrm{~g}$. Appropriate concentration of the extract was then subsequently made by dilution with distilled water into $200 \mathrm{mg} / \mathrm{kg}$ body weight and administered to the animals.

\section{Experimental Design}

Animals

Ninety-day-old female albino rats of Wistar strain (Rattus norvegicus) obtained from the National Institute of Nutrition, Hyderabad, weighing $140 \pm 10 \mathrm{~g}$ were used for the present investigation. The rats were maintained in a temperature controlled animals' quarter with $12 \mathrm{~h}$ dark: $12 \mathrm{~h}$ light schedule and were fed standard rat pellet diet (Broke Bond, Lipton India Ltd., India) and drinking water ad libitum. The animals were dewormed with albendazole (Bendex-400, Protec Cipala Ltd., India) (10 mg/kg body weight, orally), before the initiation of the experiment. The females were mated with males at a ratio of 2:1. Cohabitation began at approximately $16.30 \mathrm{~h}$ on each mating day. On the following morning the females were removed from the mating cages and smeared individually for the presence of sperm in the vaginal lavage. The presence of sperm in the vaginal lavage is indicative that the females mated, and those were selected for further studies. The pregnant animals were then allowed to give birth. The mother animals with female pups were divided into the following groups:

Group I: control

Group II: 50 ppm

Group III: 200 ppm

The minimum (50 ppm) and maximum effective doses (200 ppm) of Cd were selected [16], and the mother rats along with female pups were treated with $\mathrm{Cd}$ in the form of cadmium chloride and the crude plant extract mixed in drinking water from 0 day post-parturition (pp) to 65 days pp.

Subgroup I: 45-day-old rat-puberty occurred Subgroup II: 65-day-old rat-full growth of ovary

At the end of the experimental period, animals were killed by cervical decapitation, and the uteri were dissected and washed with ice-cold saline. A 10\% homogenate (100 $\mathrm{mg}$ in $1 \mathrm{ml}$ buffer) of washed tissue was prepared in $0.1 \mathrm{M}$ Tris- $\mathrm{HCl}$ buffer, $\mathrm{pH} 7.4$, and used for the assay of the following biochemical parameters.

\section{Protein}

The protein content was determined by the method of Lowry et al. [17]. The total protein content was expressed as gram $/ 100 \mathrm{~g}$ tissue. 
Tissue Anti-oxidizing Enzymes

\section{Superoxide Dismutase}

The enzyme was assayed according to the method of Marklund and Marklund [18]. The enzyme activity was expressed as units/milligram protein.

\section{Catalase (CAT)}

The activity of catalase was assayed by the method of Sinha [19]. The activity of catalase was expressed in units/ milligram protein ( 1 unit is the amount of enzyme that utilizes $1 \mu \mathrm{mol}$ of hydrogen peroxide/min).

\section{Glutathione Peroxidase}

The activity of GPx was determined by the method of Rotruck et al. [20]. The enzyme activity was expressed as units/protein (1 unit is the amount of enzyme that converts $1 \mu \mathrm{mol} \mathrm{GSH}$ to GSSG in the presence of hydrogen peroxide/min).

\section{Glutathione-s-transferase}

This enzyme was assayed by the method of Habig et al. [21]. The enzyme activity was expressed as units/milligram protein ( 1 unit is the amount of enzyme that converts $1 \mu \mathrm{mol}$ GSH to GSSG in the presence of hydrogen peroxide/min).

\section{Statistical Analysis}

All data were presented as means \pm standard error of the mean (SEM). Statistical significance was calculated using ANOVA to test the significance of individual variations. The value of probability was obtained from the degree of freedom by using standard table value, given by Fischer and Yates [22]. The level of significance was assessed at $p<0.05$.

\section{Results}

Antioxidant Enzymes

\section{Superoxide Dismutase}

Significant duration-dependent decrease in SOD activity was noted in animals treated with $\mathrm{Cd}$ when compared to controls. SOD levels were enormously reduced in the ovary of $50 \mathrm{ppm}$ and $200 \mathrm{ppm}$ Cd-exposed rats during 45 and 65 days PND. The present study was undertaken to evaluate the antioxidant activity of a selected herbal extract. The SOD level was significantly $(p<0.05)$ increased in herbal administered group in both age groups (45 and 65 days) (Fig. 1).

\section{Catalase (CAT)}

The activity of catalase was significantly decreased in the 45th and 65th days of the animals' exposure to $\mathrm{Cd}$ when compared to control. But in those treated with herbal extract and $\mathrm{Cd}$ there was a significant increase in the catalase levels (Fig. 2).

\section{Glutathione Peroxidase}

A duration-dependent response was observed in exposed rats. Animals which were persistently exposed to $\mathrm{Cd}$
Fig. 1 Effect of herbal extract and cadmium exposure on ovarian SOD in developing female rats. Each bar represents the mean and SEM $(n=4)$. Statistical significance of difference among groups at $p<0.05$; control versus $50 \mathrm{ppm}$ cadmium treatment; $50 \mathrm{ppm}$ cadmium treatment versus $50 \mathrm{ppm}$ cadmium treatment along with herbal administration (both 45 and 65 days)

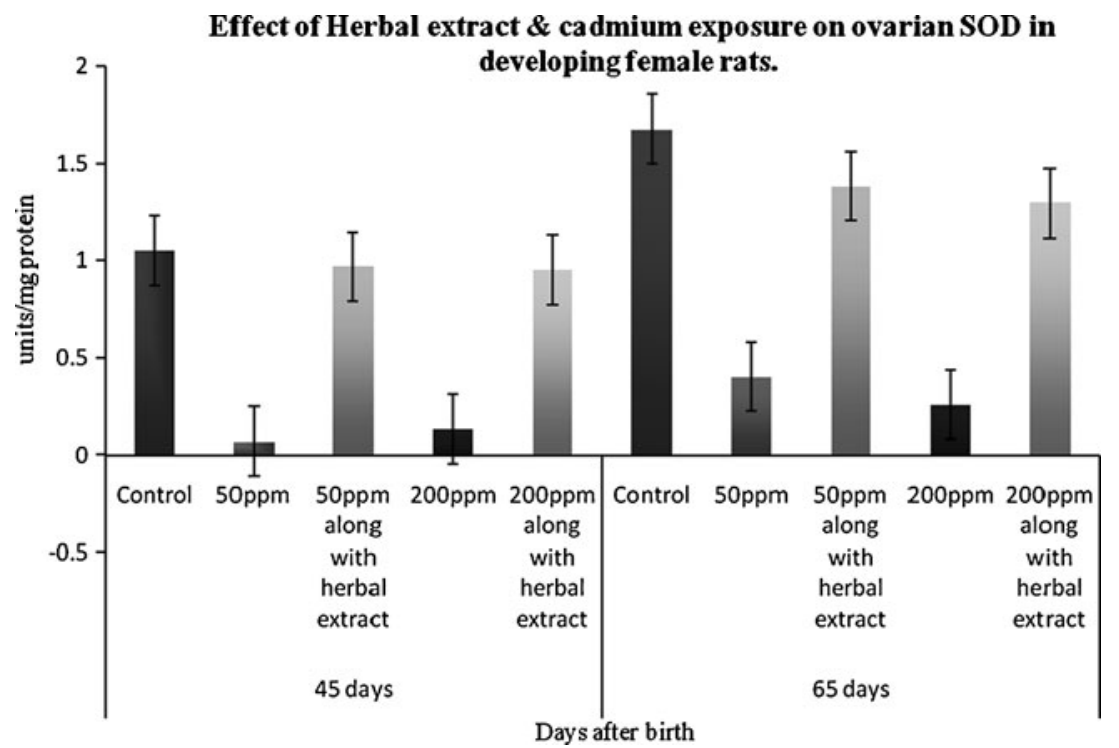


Fig. 2 Effect of herbal extract and cadmium exposure on ovarian catalase in developing female rats. Each bar represents the mean and SEM $(n=4)$. Statistical significance of difference among groups at $p<0.05$; control versus $50 \mathrm{ppm}$ cadmium treatment; $50 \mathrm{ppm}$ cadmium treatment versus $50 \mathrm{ppm}$ cadmium treatment along with herbal administration (both 45 and 65 days)

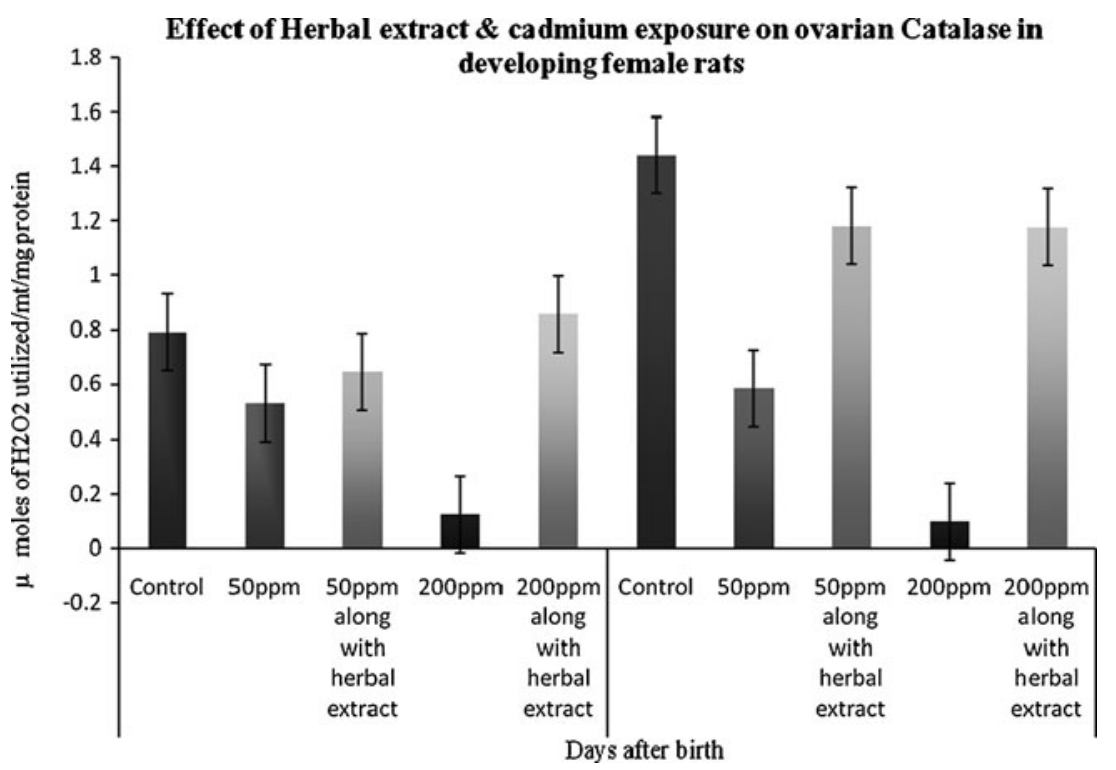

showed a significant suppression of ovarian GPx activity in the 45th PND when compared to control. A marked increase in activities of GPx antioxidant enzymes was observed in herbal extract administered group (Fig. 3).

\section{Glutathione-s-transferase}

A low level of GST activity was observed in both the Cdexposed groups of rat ovaries when compared to control. The depletion of GST activity was greater in the ovary of 45th-day treated animals. The GST activity was found to be significantly $(p<0.05)$ increased in herbal administered group when compared to control and Cd-only treated group (Fig. 4).

\section{Discussion}

The role of antioxidants is to neutralize the excess of free radicals, to protect the cells from toxic effects and to contribute to disease prevention. [23]. In the present study, a significant decrease in SOD activity was observed in the ovaries of the 45-day and 65-day age group animals (Fig. 1). The activity of another antioxidant enzyme, catalase, was also lowered in the ovaries of 45-day and 65-day age groups of Cd-exposed animals (Fig. 2). This is in accordance with the findings of previous studies. Studies by some authors have shown that $\mathrm{Cd}$ inhibits the activity of the majority of enzymes involved in AOS [24,25], inducing an increased production of free radicals, lipid peroxidation
Fig. 3 Effect of herbal extract and cadmium exposure on ovarian GPx in developing female rats. Each bar represents the mean and SEM $(n=4)$. Statistical significance of difference among groups at $p<0.05$; control versus $50 \mathrm{ppm}$ cadmium treatment; 50 ppm cadmium treatment versus $50 \mathrm{ppm}$ cadmium treatment along with herbal administration (both 45 and 65 days)
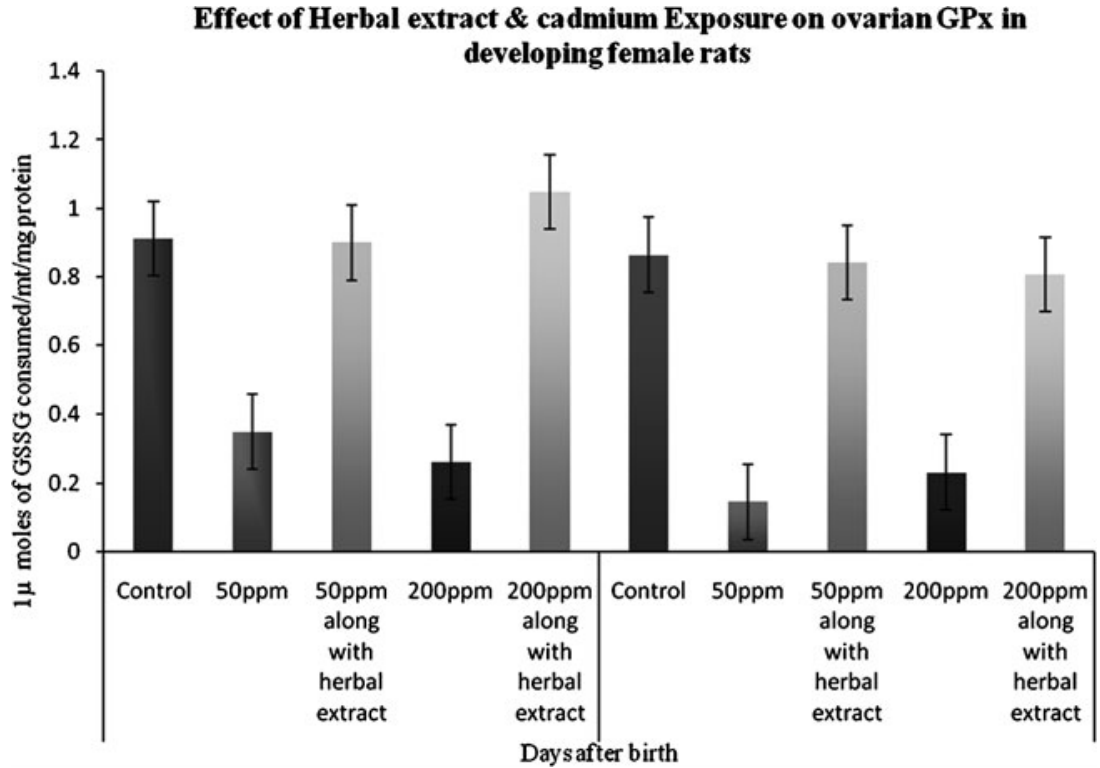
Fig. 4 Effect of herbal extract and cadmium exposure on ovarian GST in developing female rats. Each bar represents the mean and SEM $(n=4)$. Statistical significance of difference among groups at $p<0.05$; control versus $50 \mathrm{ppm}$ cadmium treatment; $50 \mathrm{ppm}$ cadmium treatment versus $50 \mathrm{ppm}$ cadmium treatment along with herbal administration (both 45 and 65 days)

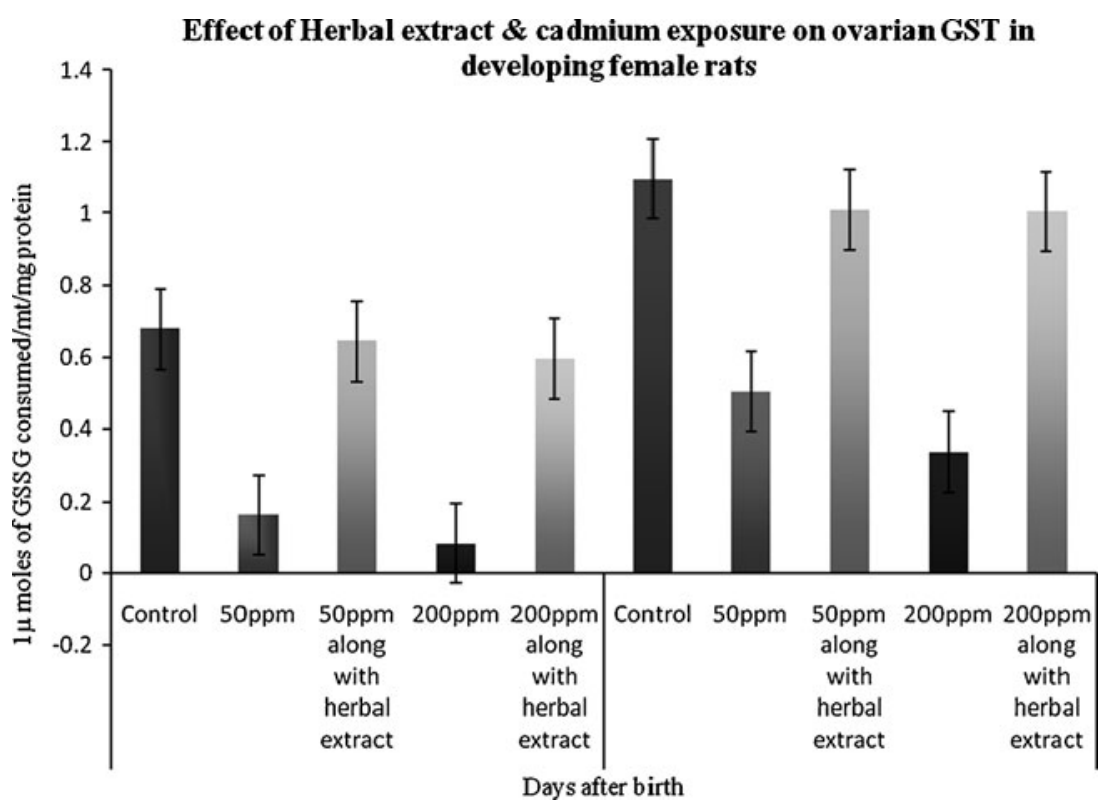

and destruction of cell membranes [26,27]. SOD has proven a useful probe for studying the free radicals in reactions involving oxygen, since it acts as a defense against oxidative tissue damage by dismutation of superoxide radicals [28]. SOD also plays an important role in the regulation of the luteal function during pregnancy [9]. Long-term exposure to $\mathrm{Cd}$ increases lipid peroxidation and causes inhibition of SOD activity, resulting in oxidative damage to liver, kidney and testes [11]. Also in the Cdtreated group, hepatic LPO increased and SOD and CAT activities were decreased, as observed in earlier studies [29,30]. The increased LPO may be due to decreased activities of SOD and CAT, the free radical scavenging enzymes [31].

Antioxidant-based drug formulations are used for the prevention and treatment of complex diseases like atherosclerosis, stroke, diabetes, Alzheimer's disease and cancer [32]. There is evidence that indigenous antioxidants may be useful in preventing the deleterious consequences of oxidative stress, and there is increasing interest in the protective biochemical functions of natural antioxidants contained in spices, herbs and medicinal plants [33]. In the present study a significant increase in SOD and catalase activity was observed in the ovaries of 45-day and 65-day age group animals (Figs. 1 and 2). Piper species, commonly used in diet and traditional medicine, were assessed for their antioxidant potential. P. cubeba Linn increased antioxidants like SOD and catalase activities [13]. Catalase activity was predominant in P. longum [14]. There are more than 50 antioxidants isolated from rhizomes of ginger [34]. Z. officinale (ginger) significantly lowers lipid peroxidation by maintaining the activities of the antioxidant enzymes: SOD, catalase and glutathione peroxides in rats [12]. C. nurvala shows the highest SOD activity (122.53 units/min/mg) [35]. $\mathrm{H}$. indicus root bark has also been reported to possess antioxidant property [36].

The decreases in GPx and GST activities in the ovaries of 45-day and 65-day age group animals are given in Figs. 3 and 4. A drastic reduction in GPx activity was noticed in the ovary of 45-day age group rats treated with $50 \mathrm{ppm} \mathrm{Cd}$ when compared to control. A similar trend was also noticed in GPX activity in the ovary of 65-day-old rats treated with $50 \mathrm{ppm}$ Cd when compared to control. Glutathione, the cofactor for the lipid hydrogen-peroxide detoxifying enzyme, GPx, is also present in high concentrations in ovarian tissue [37]. Numerous reports in animal models have shown that $\mathrm{Cd}$ intoxication significantly increases the malondialdehyde (MDA) and glutathione peroxidase (GSH-Px) [38,39]. Free radicals generated by $\mathrm{Cd}$ are scavenged by GSH directly or via the GSH peroxidase/GSH system [28]. The GST enzyme has an important role in the detoxification of xenobiotics, drugs and carcinogens, and thus protects the cells against redox cycling and oxidative stress $[40,41]$.

The increases in GPx and GST activities in the ovaries of 45day and 65-day age group animals are given in Figs. 3 and 4. This was consistent with the previous findings that $\mathrm{N}$. sativa oil increases glutathione (GSH) and SOD [42]. C. longa protects against ischemia-induced changes by increasing the antioxidant defense mechanisms [43]. B. juncea administered to animal groups increases activity of SOD and catalase. It also sharply increased the activity of glutathione reductase (GSH), GPx and GST in the experimental group compared to the controls [44]. The N. sativa oil produced an increase in glutathione level in the stomach [45]. N. sativa oil has been reported in other publications to possess antioxidant activity [46]. 


\section{Conclusion}

In the present study, $\mathrm{Cd}$ treatment to female Wistar rats inhibited the action of enzymes involved in the scavenging of ROS. However, the inhibited antioxidant enzyme levels were elevated significantly due to the action of the bioactive principles present in the herbal antioxidant restoration mixture. The protective role of the extracts of 17 plant products in the reproductive functioning had been well known to traditional healers and needs further phytochemical analysis.

\section{References}

1. Morrow H (2001) Cadmium and cadmium alloys. In. KirkOthmer encyclopedia of chemical technology. Wiley, New York, 471-507. Nutrition Reviews 52: 253-265

2. Herron N (2003) Cadmium compounds. In: Kirk-Othmer encyclopedia of chemical technology, vol. 4. Wiley, New York, pp 507-523

3. Massanyi P, Uhrin V, Toman R, Pivko J, Lukac N, Zs F, Somosy Z, Fabis M, Danko J (2005) Ultrastructural changes of ovaries in rabbits following cadmium administration. Acta Vet Brno 74:2935

4. Kjellstrom T (1979) Exposure and accumulation of cadmium in populations from Japan, the United States, and Sweden. Environ Health Perspect 28:169-197

5. Massanyi P, Uhrin V, Sirotkin AV, Paksy K, Forgacs ZS, Tomom R, Kovacik J (2000) Effects of cadmium on ultrastructure and steroidogenesis in cultured porcine ovarian granulose cells. Acta vet Brno 69:101-106

6. Toman R, Massamyi P, Uhrin V (2002) Changes in the testis and epididymis of rabbits after an inliapcitoneal and peroral administration of cadmium. Trace Elem Electrolytes 19:114-117

7. Sarkar S, Yadov P, Bhatnagar D (1998) Lipid peroxidative damage on cadmium exposure and alterations in antioxidant defence system in rat erythrocytes: a study with relation to time. Bio Metals 11:153-157

8. Zikic RV, Stajn AS, Ognjanovic BI, Saicic ZS, Kostic MM, Pavlovic SZ, Petrovic VM (1998) The effect of cadmium and selenium on the antioxidant enzyme activities in rat heart. $\mathrm{J}$ Environ Pathol Toxicol Oncol 17:259-264

9. Pajavic SB, Saicic ZS (2008) Modulation of antioxidant enzymes activities by sexual steroid hormone. Physio Res 57:801-811

10. Shi W, Li CM, Tyler PC, Furneaux RH, Cahill SM, Girvin ME, Grubmeyer C, Schramm VL, Almo SC (1999) The 2.0 structure of malarial purine phosphoribosyltransferase in complex with a transition-state analogue inhibitor. Biochemistry 3(38(31)):98729880

11. Patra RC, Swarup D, Senapati SK (1999) Effects of cadmium on lipid peroxides and superoxide dismutase in hepatic, renal and testicular tissue in rats. Vet Human Toxicol 41:65-67

12. Ahmed RS, Seth V, Banerjee BD (2000) Influence of dietary ginger (Zingiber officinale Rosa on antioxidant defense system in rat: comparison with ascorbic acid. Indian J Exp Biol 38:604-606

13. Aqil F, Ahmed I, Mehmood Z (2006) Anti-oxidants and free radical scavenging properties of twelve traditionally used Indian medicinal plants. Turk J Biol 30:177-183

14. Karthikeyan J, Rani P (2003) Enzymatic and non-enzymatic antioxidants in selected Piper species. Indian J Exp Biol 41:135140
15. Uboh FE, Edet EE, Eteng MU, Eyong EU (2010) Comparative effect of aqueous extract of $\mathrm{P}$. guajava leaves and ascorbic acid on serum sex hormones levels in male and female rats. J Appl Sci Res 6(4):275-279

16. Samuel BJ (2001) Reproductive toxicity of chromium on ovarian development in female Wistar rats-an endocrine and a biochemical approach, Chapter I \& III, Ph.D. Thesis

17. Lowry OH, Rosebrough NJ, Farr AL, Randall RJ (1951) Protein measurement with the folin phenol reagent. J Biol Chem 193:265275

18. Marklund S, Marklund G (1974) Involvement of superoxide anion radical in the auto oxidation of pyrogallol and a convenient assay for superoxide dismutase. Eur J Chem 47:469-474

19. Sinha AK (1972) Colorimetric assay of catalase. Analalytical Biochemistry 47:389-395

20. Rotruck JT, Pope AC, Ganther HE, Swanson AB, Hafeman DG, Hoekstra WG (1973) Selenium: biochemical role as a component of glutathione peroxidases. Science 179:588-590

21. Habig WH, Pabst MJ, Jakoby WB (1973) Glutathione-S-transferase. The first enzymatic step in mercapturic formation. J Biol Chem 249:7130-7139

22. Fischer RA, Yates F (1948) In: Statistical tables for biological, agricultural and medical Research. Oliver and Boyd, London

23. Douglas RM, Chalker EB, Treacy B (2000) Vitamin C for preventing and treating the Cochrane. Database Syst Rev 2:10000980

24. Casalino E, Calzaretli G, Sblano C, Landriscina C (2002) Molecular inhibitory mechanisms of antioxidant enzymes in rat liver and kidney by cadmium. Toxicology 179:37-50

25. Jamall IS, Sprowls JJ (1987) Effects of cadmium and dietary selenium on cytoplasmic and mitochondrial antioxidant defense systems in the heart of rats fed high dietary copper. Toxicol Appl Pharmacol 87:102-110

26. Casalino E, Sblano C, Landriscina C (1997) Enzyme activity alteration by cadmium administration to rats: the possibility of iron involvement in lipid peroxidation. Arch Biochem Biophys 346:171-179

27. Kostic MM, Ognijanovic B, Dimitrijevic S, Zikic RV, Stajn A, Risic GL (1993) Cadmium-induced changes of antioxidant and metabolic status in red blood cells of rats: in vivo effects. Eur J Haematol 51:86-92

28. Ognijanovic BI, Pavlovic SZ, Maletic SD, Zikic RV, Stajn AS, Radijicic RM et al (2003) Protective influence of vitamin E on antioxidant defense system in the blood of rats treated with cadmium. Physiol Res 52:563-570

29. Jamall IS, Smith C (1965) Effects of cadmium on glutathione peroxidase, superoxide dismutase and lipid peroxidation in the rat heart: possible mechanisms of cadmium cardio toxicity. Toxicol Appl Pharmacol 80:33-42

30. Stracey H, Louris R, Cantilena JR, Klaassen CD (1980) Cadmium toxicity and lipid peroxidation in isolated rat hepatocytes. Toxicol Appl Pharmacol 53:470-480

31. Jawahar B, Samuel JA, Stanley DP, Roopha GV, Anbalagan J, Banu SK, Arul das MM (2010) Lactational hexavalent chromium exposure-induced oxidative stress in rat uterus is associated with delayed puberty and improved gonadotropin levels. Hum Exp Toxicol 000(00):1-11

32. Devasagayam TPA, Tilak JC, Boloor KK et al (2004) Review: free radicals and anti-oxidants in human health: Carr stat fut prosp. JAPL 52:794-804

33. Noda Y, Metal AK (1997) Hyduoxyl and superoxide anion radical scavenging activities of natural souuce anti-oxidants using the computerized JES-FR 30 ESR spectrophotometer system. Bioch Mol Biol Inter 42:35-44

34. Masuda Y, Kikuzaki H, Hisamoto M, Nakatani N (2004) Antioxidant properties of gingerol related compounds from ginger. Biofactors 21:293-296 
35. Archana kumari, Poonam kakkar (2008) Screening of antioxidant potential of selected barks of Indian medicinal plants by multiple in vitro assays. Biomed Environ Sci 21:24-29

36. Ravi shankara MN, Shrivastava N, Padh HZ, Rajani M (2002) Evaluation of antioxidant properties of root barks $\mathrm{H}$. Indicus (anantmul). Phytomedicine 9:153

37. Mattison DR, Shiromizu K, Pendergrass JA, Thorgeirsson SS (1983) Ontogeny of ovarian glutathione and sensitivity to primordial oocytes destruction by cyclophosphamide. Pediat Pharmacol 3:49-55

38. Cosic DD, Bulat ZP, Ninkovic M, Malicevic Z, Matovic V (2007) Effect of subacute cadmium intoxication iron and lipid peroxidation in mouse liver. Toxicol Lett 172:s209

39. Yang JM, Arnush M, Chen QY, Wu XD, Pang B, Jiang XZ (2003) Cadmium induced damage to primary cultures of rat Leydig cells. Reprod Toxicol 17:553-560

40. Caslino E, Sblano C, Landriscina V, Calzaretti G, Landriscina C (2004) Rat liver glutathione-s-transferase activity stimulation following acute cadmium or manganese intoxication. Toxicology 200:29-38
41. Mates M (2000) Effects of antioxidant enzymes in the molecular control of reactive oxygen species toxicology. Toxicology 153:83104

42. El-Abhar HS, Abdallah DM, Saleh S (2003) Gastroprotective activity of Nigella sativa oil and its constituent, thymoquinone, against gastric mucosal injury induced by ischemia/reperfusion in rats. J Ethnopharmacol 84(2-3):251-258

43. Dikshit M, Rastogi L, Shukla R, Srimal RC (1995) Prevention of ischemia-induced biochemical changes by curcumin and guanidine in cat heart. Indian I Med Res 101:31-35

44. Khan BA, Abraham A, Leelamma S (1996) Role of Murrays koenijii (curry leaf) and Brassica juncea (mustard) in lipid peroxidation. Indian J Physiol Pharmacol 40:155-158

45. El-Dakhakhny M, Barakat M, El-Halim MA, Aly SM (2000) Effect of Nigella sativa oil or gastric secretion and ethanol misused celcerin rats. J Ethnopharmacol 72:299-304

46. Bruits M, Bucar F (2000) Antioxidant activity of Nigella sativa essential oil. Phytother - Res 14:323-328 